ERIC MacPhail

\title{
Jean Bodin and the Praise of Superstition
}

\author{
And then for your religion professe none \\ But wonder at the diversitie of all; \\ And for your part protest, were there no other \\ But simply the laws o' th' land, you could content you: \\ Nic Machiavel and monsieur Bodine both \\ Were of this mind. \\ Ben Jonson Volpone IV, i, 22-27
}

\begin{abstract}
This essay situates the political thought of the French Renaissance prose writer Jean Bodin within the dual tradition of political theory and epideictic rhetoric. Bodin's pragmatic reappraisal of superstition, as a bulwark against atheism and anarchy, represents a sort of convergence of paradoxical encomium and political realism in the service of religious pluralism and pacification of civil war. When juxtaposed with his more famous predecessor Niccolò Machiavelli and more renowned contemporary Michel de Montaigne, Bodin's treatment of superstition, both in his vernacular masterpiece Les six livres de la République and in his neo-Latin works, emerges as a timely intervention in confessional strife and a classical adaptation of epideictic wisdom.
\end{abstract}

Keywords: rhetoric, atheism, superstition, tolerance, Bodin, Machiavelli, Montaigne

$\mathrm{T}$

he late sixteenth-century French prose writer Jean Bodin is a perplexing figure, equally renowned as a pioneering advocate of religious tolerance and as a fanatical persecutor of witches. Recently, there has been a strong revival of interest in Bodin as a political thinker and natural philosopher, but his place in the

Rhetorica, Vol. XXXVI, Issue 1, pp. 24-38. ISSN: 0734-8584, electronic ISSN: 1533-8541. (c) 2018 by The International Society for the History of Rhetoric. All rights reserved. Please direct all requests for permission to photocopy or reproduce article content through the University of California Press's Reprints and Permissions web page, http:/ / www.ucpress. edu/journals.php?p=reprints. DOI: https://doi.org/10.1525/rh.2018.36.1.24. 
rhetorical tradition remains largely though not entirely unexamined. ${ }^{1}$ While Marc Fumaroli makes no room for Bodin in his magisterial study, L'âge de l'éloquence, others are more accommodating. Gary Remer has studied Bodin in relation to the rhetoric of toleration with particular attention to his clandestine dialogue Colloquium Heptaplomeres. $^{2}$ Wayne Rebhorn highlights Bodin's ambivalence toward rhetoric, which can be both cause and cure of civil strife. ${ }^{3}$ Bodin finds no place in Victoria Kahn's study of Machiavellian rhetoric other than as an incidental antagonist to the author of the Prince. ${ }^{4}$ To supplement and extend these few precedents, I prefer to focus on epideictic rhetoric and to consider the arguments that Bodin deploys in praise of superstition, which put him in dialogue with a number of crucial figures in Western intellectual tradition who reflected on the uses of religion in politics. Through his praise of superstition, Bodin inscribes himself in a tradition that is both rhetorical and political and which, in both respects, carries on the legacy of Niccolò Machiavelli. Like Machiavelli, Bodin maintains that fear of God is the basis of social order, and from this premise he draws the inference that any religion or superstition that inculcates the fear of God has social value. Moreover, in the context of the French Wars of Religion, the praise of superstition functions as a defense of religious tolerance and as an appeal for the coexistence of Protestants and Catholics. Bodin makes clear, finally, that the limit to tolerance is defined by atheism.

In the preface which he wrote for the vernacular version of his Six books of the Republic and which he addressed to Guy du Faur de Pibrac, Jean Bodin deplores what he calls the profanation of political philosophy by ignorant authors. ${ }^{5}$ His prime example is Niccolò Machiavelli, who supposedly identified impiety and injustice as the twin foundations of a republic. To refute the first of these foundations, Bodin appeals to Polybius who, though a rank atheist himself, still

\footnotetext{
${ }^{1}$ This interest is manifested in the new editions of his work including Jean Bodin, Methodus ad facilem historiarum cognitionem, ed. Sara Miglietti (Pisa: Scuola Normale Superiore, 2013) and Jean Bodin, Les Six Livres de la République. De Republica libri sex, ed. Mario Turchetti (Paris: Classiques Garnier, 2013-).

${ }^{2}$ Gary Remer, Humanism and the Rhetoric of Toleration (University Park: Penn State University Press, 1996) 203-230.

${ }^{3}$ Wayne Rebhorn, The Emperor of Men's Minds. Literature and the Renaissance Discourse of Rhetoric (Ithaca: Cornell University Press, 1995) 129-132.

${ }^{4}$ Victoria Kahn, Machiavellian Rhetoric from the Counter-Reformation to Milton (Princeton: Princeton University Press, 1994) 96.

${ }^{5}$ Jean Bodin, Les six livres de la République (Paris: Jacques Du Puys, 1583; reprint Aalen: Scientia, 1961), fol. a ii $\mathrm{r}^{\mathrm{o}}$ to a $\mathrm{v} \mathrm{r}^{\mathrm{o}}$.
} 
recognizes the importance of religion and even maintains that Rome excelled all other peoples by virtue of religion. ${ }^{6}$ As for the other pillar of the Machiavellian republic, injustice, Bodin recounts the anecdote, derived ultimately from Cicero's De republica, of the Greek philosopher Carneades, who came on an embassy to Rome, where he pronounced a speech in praise of injustice one day and another in praise of justice the next. Bodin approves of Cato's proposal to ban such orators from the Republic. To teach injustice to princes, Bodin insists, is a dangerous "incongruity," but perhaps not as dangerous, he acknowledges, as to teach rebellion to subjects; ${ }^{7}$ and so, on the threshold of his work, he stakes out a position in opposition both to the defense of tyranny by Machiavelli and to the defense of rebellion by the authors we know as the Monarchomachs, who wrote in the aftermath of the St. Bartholomew's Day Massacre. ${ }^{8}$

The République rarely mentions Machiavelli beyond the preface, ${ }^{9}$ but Bodin does revisit the issues raised in the preface in a later chapter of his work, the last chapter of book four, devoted to faction and civil discord. As Rebhorn reminds us, this is the very chapter that stages a debate in utramque partem about rhetoric itself. Among the many causes of sedition, Bodin nominates eloquence itself, in the form of "la licence qu'on donne aux harangueurs, qui guident les coeurs et volontés du peuple où bon leur semble." ${ }^{\prime 10}$ There is no lack of historical examples to illustrate the dangers posed by popular preachers or

${ }^{6}$ Bodin, République a iv ro: "et toutesfois au Polibe gouverneur et lieutenant de Scipion l'Africain, estimé le plus sage Politique de son aage, ores qu'il fust droit Atheiste, neantmoins il recommande la religion sur toutes choses, comme le fondement principal de toutes Republiques. . .quand il dit que les Romains n'ont iamais rien eu de plus grand que la religion, pour estendre les frontieres de leur Empire."

${ }^{7}$ Bodin, République a iv $\mathrm{v}^{\mathrm{o}}$ to a $\mathrm{v} \mathrm{r}^{\mathrm{O}}$ : “ $\mathrm{C}^{\prime}$ est donques une incongruité bien lourde en matiere d'estat, et d'une suite dangereuse, enseigner aux Princes des reigles $\mathrm{d}$ 'iniustice pour asseurer leur puissance par tyrannie. ... Il y en a d'autres contraires et droits ennemis de ceux cy qui ne sont pas moins, et peut estre plus dangereux, qui soubs voile d'une exemption de charges, et liberté populaire, font rebeller les suiets contre leurs Princes naturels, ouvrant la porte à une licentieuse anarchie, qui est pire que les plus fortes tyrannies du monde."

${ }^{8}$ The 1576 preface to the République was not Bodin's last word on the Monarchomachs. See JHM Salmon, "Bodin and the Monarchomachs" in Jean Bodin, ed. Horst Denzer (Munich: Beck, 1973) 359-378 and Paul-Alexis Mellet, Les traités monarchomaques (Geneva: Droz, 2007) 347-352.

${ }^{9}$ As Alberto Tenenti remarks in his study "La prima edizione della 'République' e l'opera di Machiavelli," after the preface, "A parte qualche rara eccezione, Machiavelli si eclissa." He identifies three chapters of the République that mention Machiavelli by name: I, 8; V, 1; VI, 4. See Tenenti, Credenze, ideologie, libertinismi tra Medioevo ed Età moderna (Bologna: Il Mulino, 1978) 227.

${ }^{10}$ Bodin, République 660. 
"les prescheurs mutins," who played such a key role in prolonging the French Wars of Religion. All too often in the course of history, eloquence has proven itself to be a sharp knife in the hands of a madman: "C'est donc un couteau fort dangereux en la main d'un furieux homme, que l'eloquence en la bouche d'un harangueur mutin."11 This is a venerable topos, what we might call a metarhetorical commonplace, that certifies Bodin's excellent humanist training. Already, Marsilio Ficino had characterized rhetoric in similar terms in the argumentum to his translation of Plato's Gorgias: "quasi eloquentia sine sapientia sit ensis acutus in manibus furiosi" and Giovanni Pico della Mirandola echoed this sentiment in a letter to Ermolao Barbaro: "insipiens eloquentia, uti gladius in furentis manu, non obesse maxime non potest." 12 We may recall that Pico's letter is a prime example of the paradoxical encomium, namely a praise of ineloquence. Yet, rhetoric is also a civilizing force and a rampart against sedition: “Et n'y a point de moyen plus grand d'appaiser les seditions, et contenir les subiects en l'obeissance des Princes, que d'avoir un sage et vertueux prescheur, par le moyen duquel on puisse fleschir et ployer doucement les coeurs des plus rebelles." ${ }^{\prime 13}$ Only rhetoric can neutralize the dangers of rhetoric. It is the contention of this paper that Bodin himself takes on this role of the orator in the public service, not by public preaching or deliberative rhetoric, but by a particular exercise of epideictic rhetoric. If we return to the beginning of this same chapter (IV, 7), we can see that Bodin provides a clue with his allusion to a notorious figure of the second sophistic.

Book four, chapter seven of the Republic begins with an axiom: faction and sedition are bad for every kind of republic. ${ }^{14}$ To say otherwise, to praise them is a mere paradox, as if one were to praise the quartan fever like the sophist Favorinus of Arles. ${ }^{15}$ This axiom is a self-conscious rejoinder to the notorious thesis of the Discorsi that Rome owed its greatness to the conflicts between the patricians and the people. In book one, chapter four of the Discorsi, Machiavelli

\footnotetext{
${ }^{11}$ Bodin, République 661.

${ }^{12}$ Ficino, Opera omnia, vol. 2, pt. 1 (Basel, 1576; reprint Turin, 1959) 1315 and Giovanni Pico della Mirandola's letter to Ermolao Barbaro of June 3, 1485 in Eugenio Garin, Prosatori Latini del Quattrocento (Milan: Ricciardi, 1952) 820.

${ }^{13}$ Bodin, République 662.

${ }^{14}$ Bodin, République 634: "Premierement nous poserons ceste maxime, que les factions et particularités sont dangereuses, et pernicieuses en toute sorte de Republique."

${ }^{15}$ Bodin 635: "aussi pourroit-on loüer les maladies: comme Favorin loua grandement la fievre quarte."
} 
speaks in praise of what he calls " $\mathrm{i}$ tumulti" or the civil discords and upheavals of early Republican Rome that led to the establishment of the tribunes of the people. ${ }^{16}$ Moreover, he is conscious of advancing a paradox and of praising what others blame in his appreciation of tumult, which he regards as the prime or first cause of Roman liberty. ${ }^{17}$ This thesis proved to be, as its author anticipated, quite provocative. Already in 1530, Francesco Guicciardini was at pains to refute Machiavelli's paradoxical reasoning in his Considerations on the Discourses. In the commentary to Discorsi I, 4, Guicciardini says that to praise the social divisions of the Roman Republic which led to the establishment of the tribunes is like praising an illness for the efficacy of the remedy applied to it. ${ }^{18}$ This is the argument developed by Bodin and another foe of Machiavelli, even though neither could have read the Considerations in print, since the editio princeps was 1857.

In 1576, the same year that Bodin published Les six livres de la République, the Protestant jurist Innocent Gentillet published a laborious and fanatical rebuttal of Machiavelli, known as the Anti-Machiavel. This work reduces the Prince and the Discourses to a series of numbered maxims that Gentillet rebuts at great length. Maxim 31 of part three responds to Discorsi I, 4 and to its praise of tumult. Gentillet suggests that Machiavelli's argument resembles the logic of a certain philosopher, mentioned in Aulus Gellius' Attic Nights (17.12), who praised the quartan fever. ${ }^{19}$ The philosopher whose name Gentillet doesn't remember is correctly identified by Bodin as Favorinus. In other words, both Bodin and Gentillet recognize Machiavelli's praise of tumult as a paradoxical encomium in the tradition of sophistic rhetoric, and both ostensibly repudiate this tradition.

${ }^{16}$ “Io non voglio mancare di discorrere sopra questi tumulti che furano in Roma dalla morte de' Tarquini alla creazione de' tribuni, e dipoi alcune cose contro la opinione di molti, che dicono Roma essere stata una republica tumultuaria. . . . E se i tomulti furano cagione della creazione de' tribuni, meritano somma laude." Niccolò Machiavelli, Discorsi sopra la prima Deca di Tito Livio, ed. Francesco Bausi (Rome: Salerno Editrice, 2001) 33-36.

${ }^{17}$ Machiavelli 33: "Io dico che coloro che dannono i tumulti intra i nobili e la plebe, mi pare che biasimino quelle cose che furano prima causa del tenere libera Roma."

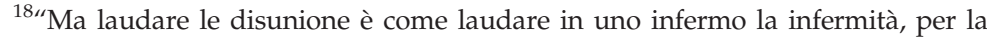
bontà del remedio che gli è stato applicato." Francesco Guicciardini, Considerazioni sui "Discorsi" del Machiavelli in Opere, ed. Emanuella Lugnani Scarano, vol. 1 (Turin: UTET, 1970) 616. I owe this reference to the sagacity of Thomas Berns.

${ }^{19}$ “'Ceste raison ressemble à l'argument d'un certain philosophe, duquel Aulugelle se mocque, qui vouloit soustenir que la fievre quartaine est une bonne chose, parce qu'elle fait devenir les gens sobres et temperans, et les garde de trop boire et manger." Innocent Gentillet, Anti-Machiavel, ed. Edward Rathé (Geneva: Droz, 1968) 555. 
However, if we return to book four, chapter seven of the Republic, we can see that Bodin emulates Machiavelli's rhetorical performance, not in praise of civil discord, which he disparages, but in praise of superstition. The topic of faction and sedition in the republic leads to the question of how to deal with religious discord or "les guerres touchant le faict de la Religion" (652) which have spread throughout Europe in Bodin's lifetime. Bodin's first principle is that the state should never tolerate any debates about religion, for to debate a religious belief is to weaken it and encourage disbelief.

Mais la Religion estant receuë d'un commun consentement, il ne faut pas souffrir qu'elle soit mise en dispute: car toutes choses mises en dispute, sont aussi revoquees en doute: or c'est impieté bien grande, revoquer en doute la chose dont un chacun doit estre resolu et asseuré: d'autant qu'il n'y a chose si claire et si veritable qu'on n'obscurcisse, et qu'on n'esbranle par dispute: mesmement de ce qui ne gist en demonstration, ny en raison, ains en la seule creance. ${ }^{20}$

As if to illustrate his point, Bodin mentions some ancient philosophers who questioned the endoxa or received beliefs of their society: Anaxagoras maintained that snow is black, Favorinus said that fever is good for you, and Carneades praised injustice (653). All these epideictic performances merit scorn, but it is even worse to question religious beliefs. After all, even notorious atheists like Polybius recognize that religion is the foundation of the state (653). In this way, the chapter on civil war echoes the preface to the Republic, while insinuating a critique of the widespread policy of secular authorities in the European Renaissance to organize colloquies or debates in a vain attempt to pacify religious tensions. $^{21}$

Far better, in Bodin's estimation, is the policy that we would call, but that he does not call religious tolerance. ${ }^{22}$ The model of this policy,

\footnotetext{
${ }^{20}$ Bodin, République 652. Estienne Pasquier subscribes to the same view in a letter of 1585 to Nicolas Brûlart: “Ouvrez la porte aux disputes, il n'y a article de foy, qu'un esprit mal né et visqueux, ne puisse revoquer en doute." Estienne Pasquier, Lettres historiques pour les années 1556-1594, ed. D. Thickett (Geneva: Droz, 1966) 226.

${ }^{21}$ For Joseph Lecler, "L'ancienne politique des colloques, prônée jadis par les humanistes chrétiens, apparaît donc à Bodin comme définitivement condamnée par l'expérience." Histoire de la tolérance au siècle de la Réforme, vol. 2 (Paris: Aubier, 1955) 155. Georg Roellenbleck arrives at a similar conclusion in "Der Schluss des Heptaplomeres und die Begründung der Toleranz bei Bodin" in Jean Bodin (as in note 8 above) 63-64.

${ }^{22}$ For Renaissance usage, see William Huseman, "The Expression of the Idea of Toleration in French during the Sixteenth Century," The Sixteenth Century Journal 15 (1984) 293-310. Roellenbleck 65 emphasizes the political expediency of religious tolerance in Bodin's thought and opposes this sort of tolerance to religious individualism,
} 
in the Republic as in the Colloquium Heptaplomeres, is the Ottoman Empire where, according to a commonplace of Renaissance thought, the subjects of the empire enjoy absolute freedom of conscience. ${ }^{23}$ Pierre Belon gives voice to this commonplace in his travel account first published in 1553 under the title Les observations de plusieurs singularitez et choses memorables, in the chapter on Armenia:

Il est permis à toutes les religions chrétiennes vivant en Turquie d'avoir chacune son église à part. Car les Turcs ne contraignent personne de vivre à la mode turquoise, ains est permis à un chacun vivre en sa loy. ${ }^{24}$

Bodin summarizes this observation as follows:

Mais le Roy des Turcs, qui tient une bonne partie de l'Europe, garde sa Religion aussi bien que Prince du monde, et ne force personne, ains au contraire permet à chacun de vivre selon sa conscience. ${ }^{25}$

In Bodin's view, the prince should never force the conscience of his subjects, for intolerance is likely to breed atheism: if you deny people their own religion, they won't want any religion. ${ }^{26}$ This striking argument, which first appears in the 1579, Lyon edition of Les six livres de la République (the sixth in Roland Crahay's numbering), ${ }^{27}$ does not originate with Bodin. Already in 1561, the anonymous author of the Exhortation aux Princes et Seigneurs du Conseil Privé du Roy warned the ruling class that religious persecution promotes atheism, and this warning was echoed in a remonstrance of Philippe DuplessisMornay addressed to the Estates General in $15766^{28}$ Since Bodin

which has no place in Bodin's model of the state. For an exponent of religious individualism, we can turn to Pierre Bayle, who justified the policy of tolerance on religious rather than political grounds. See Elisabeth Labrousse, "Note à propos de la conception de la tolérance au XVIIe siècle," Studies on Voltaire and the Eighteenth Century 56 (1967) 799-811.

${ }^{23}$ See François Berriot, "Islam et liberté de conscience à la Renaissance" in $L a$ liberté de conscience (XVIe-XVIIe siècles) Actes du Colloque de Mulhouse et Bâle (1989) (Geneva: Droz, 1991) 173-190 and Claude Postel, La France-Turquie (Paris: les Belles Lettres, 2013) 196-202.

${ }^{24}$ Pierre Belon, Voyage au Levant: les observations de Pierre Belon de Mans, ed. Alexandra Merle (Paris: Editions Chandeigne, 2001) 464.

${ }^{25}$ Bodin, République 654.

${ }^{26}$ Bodin 655: "Autrement il adviendra que ceux qui sont frustrés de l'exercice de leur Religion, et desgoustés des autres, deviendront du tout atheistes."

${ }^{27}$ Roland Crahay, D'Erasme à Campanella (Bruxelles, 1985) 153. See also Roland Crahay, Marie-Thérèse Isaac, Marie-Thérèse Lenger, Bibliographie critique des éditions anciennes de Jean Bodin (Académie Royale de Belgique, 1992) 109.

${ }^{28}$ Speaking on behalf of the Protestant forbidden to practice his religion, the author of the Exhortation says, "Et ainsi au lieu d'adorer mon Dieu. . . , je commenceray par une nonchalance d'extravaguer en mes discours, me submergeant au gouffre et abysse d'un 
developed the same argument sometime between the 1576 edition and the 1579 edition, he may have been influenced by Duplessis-Mornay's pamphlet. In Bodin's case, the warning against atheism serves to exonerate superstition. In a well-crafted period, he insists that, just as the worst tyranny in the world is preferable to anarchy, so the most powerful superstition is less harmful than atheism:

Et tout ainsi que la plus forte tyrannie n'est pas si miserable que l'anarchie, quand il n'y a ny Prince ny Magistrat: aussi la plus forte superstition du monde, n'est pas à beaucoup pres si detestable que l'atheïsme. ${ }^{29}$

Admittedly, it is not a particularly ringing praise of superstition to say that it is less detestable than the alternative, and indeed, in other contexts, Bodin denounces superstition. ${ }^{30}$ In this version, the Republic could probably do without either superstition or atheism.

Almost predictably, Bodin's advocacy of freedom of conscience and his appeal to the model of the Ottoman Empire earned him an enduring reputation of atheism among Catholic polemicists. In his Ragguagli di Parnaso, Traiano Boccalini has Bodin indicted at Apollo's tribunal as a "pubblico e notorio Atheista," a charge confirmed by the testimony of the Impero Turco itself. ${ }^{31}$ Before Boccalini first published his Ragguagli in 1613, Antonio Possevino passed a severe judgment on Bodin's work in 1592 where he responds with special indignation to the arguments in favor of liberty of conscience that he found in the Latin version of the Republic first published in 1586 under

atheisme, qui n'apporte que voleries, pilleries, contemnement du Roy, et de vous tous." Estienne Pasquier, Écrits politiques, ed. D. Thickett (Geneva: Droz, 1966) 61. In his Remonstrance, assuming the voice of a Catholic concerned for the Protestants, Duplessis-Mornay asks "Je demande en apres, lequel nous aimons le mieux, ou que ces gens deviennent atheistes, ou bien qu'ils demeurent tels qu'ils sont. Si atheistes, ils en seroient pire pour eulx. . pour nous. . pour l'estat. . . . Or, qui doute qu'une partie n'en retombe là, si nous les laissons comme bestes, sans nulle forme de relligion." Philippe Duplessis-Mornay, Remonstrance aux Estats de Blois pour la paix in Mémoires et correspondance de Duplessis-Mornay, vol. 2 (Paris, 1824) 50. Lecler, Histoire (as in note 21 above) 41-43 traces this argument back to a speech by Jacques Bienassis on February 1, 1561 to the clergy assembled for the Estates General of Orléans.

${ }^{29}$ Bodin, République 655.

${ }^{30}$ In the Démonomanie des sorciers of 1580 , Bodin is the implacable foe of witchcraft, a notorious form of superstition. Yet, Bodin is eager to equate sorcery with atheism as a repudiation of God, to which superstition is clearly preferable. For Bodin, the worst witches are the ones who renounce their religion, even if it's the wrong religion: "Car il n'y a religion si superstitieuse, qui ne retienne aucunement les hommes es barrieres de la Loy de nature, pour obeir aux peres et meres, et aux magistratz, avec une crainte de mal faire à personne." Jean Bodin, De la démonomanie des sorciers, ed. Krause, Martin, MacPhail (Geneva: Droz, 2016) 219.

${ }^{31}$ Traiano Boccalini, Ragguagli di Parnaso (Venice, 1617) 278. 
the title De republica libri sex. ${ }^{32}$ Fabio Albergati, who had to obtain special permission from the Inquisition to read Bodin's work, denounces the intolerable doctrine of religious tolerance in his own Discorsi politici of $1602 .{ }^{33}$ A century later, Pierre Bayle was to report but not endorse these judgments in his article on Bodin for the Dictionnaire historique et critique. ${ }^{34}$ Already, in the immediate aftermath of publication and before it was ever translated into Latin, the République provoked a furious response from French Catholic preachers, as we know from the apology that Bodin wrote for his work under the pseudonym René Herpin and published in 1581. The Apologie de René Herpin devotes most of its attention to other targets and refers only in passing to "ceux qui ont crié publiquement en leurs sermons contre la Republique de Bodin. ${ }^{\prime 35}$ These preachers had two objections, both of which relate to book 4 , chapter 7 , the chapter on civil discord. The second seems most pertinent to the theme of religious tolerance:

L'autre poinct est, que Bodin tient, que le Prince souverain voyant ses suiets bandez de part \& d'autre, pour le faict de la Religion, doit passer par souffrance, ce qui ne se peut oster, comme plusieurs Empereurs Grecs \& Romains ont fait. . . ${ }^{36}$

Here, rather than speak of tolerance, Bodin employs the term "souffrance" as in "to suffer other religions" or "ceste necessite de souffrir diversité de religions" (Apologie $\left.5 \mathrm{v}^{\circ}\right)$. These other religions are also referred to as superstitions:

Quand une opinion depravee ou superstition, a gaigné les parties nobles, \& membres principaux d'une Republique, il ne faut plus user de sections \& cauteres: mais il faut l'entretenir comme un patient de diettes convenables. ${ }^{37}$

\footnotetext{
${ }^{32}$ For Possevino's Judicium (Rome, 1592) see Roland Crahay, "Jean Bodin devant la censure: la condamnation de la République," Il pensiero politico 14 (1981) 154-172.

${ }^{33}$ For Albergati's polemic, see Diego Quaglioni, "Jean Bodin nicodemita? Simulazione e dissimulazione religiosa nelle aggiunte latine alla République," Il pensiero politico 17 (1984) 319-334.

34"Chacun sait que dans les Ragguagli du Boccalin il fut condamné au feu comme un Athée, notorio Atheista, pour avoir dit dans ses Livres de la République, qu'il faut accorder aux Sectes la liberté de conscience. . . Possevin n'est pas le seul qui l'accuse d'avoir écrit bien des choses qui sont contraires à la Religion." Pierre Bayle, Dictionnaire historique et critique, $5^{\text {th }}$ edition, vol. 1 (Amsterdam, 1740) 591. Bayle collects all the testimony to Bodin's heterodoxy in Remarque $\mathrm{O}$ of the article Bodin.

${ }^{35}$ Jean Bodin, Apologie de René Herpin (Paris: Jacques Du Puys, 1581; reprint Aalen, 1961) $5 \mathrm{r}^{\circ}$.

${ }^{36}$ Bodin, Apologie $5 \mathrm{r}^{\circ}$.

${ }^{37}$ Bodin, Apologie 5v .
} 
If "superstition" designates a minority religion which is nevertheless well enough established in the state that it cannot be stamped out without destabilizing society, then in the France of 1581 Protestantism was a superstition. Not surprisingly, Bodin was no more popular with the Protestants than with the Catholics. ${ }^{38}$

When Bodin rewrote the Six books of the Republic in Latin in 1586, he expanded the chapter on civil discord to incorporate a more extensive discussion of the function of superstition in society. It is quite clear upon inspection that Bodin composed the Latin version of book four, chapter seven of the Republic while he was working on his Colloquium Heptaplomeres, which remained in manuscript at his death. The Latin text of IV, 7, echoing an argument from Machiavelli's own Discorsi, insists that the fear of God is a more potent deterrent than the fear of law in maintaining republics: "Fallunt enim qui humanis Imperiis ac legibus Respublicas non ultionis divinae metu contineri arbitrantur." ${ }^{\prime 39}$ It goes on to say that, just as there is no form of government worse than anarchy, so there is no plague more harmful to the state than atheism, adding that people are wrong to equate polytheism with atheism since, as the Latin text remarks in a passage that has no precedent in the vernacular version, superstition, of whatever sort it may be, keeps people in check and holds them to their duties whereas impiety or atheism cancels all fear of wrong doing. ${ }^{40}$ What atheism and anarchy have in common is the fact that they both breed impunity, while superstition, which in this respect seems indistinguishable from religion, fosters a salutary fear of punishment.

This is the same argument deployed by one of the speakers of the Colloquium Heptaplomeres, the Roman Catholic Coronaeus, in the context

\footnotetext{
${ }^{38}$ All the less popular given the Reformers' adamant condemnation of all forms of superstition. See Jean Delumeau, "Les réformateurs et la superstition" in Actes du Colloque L'Amiral de Coligny et son temps (Paris: Société de l'Histoire du Protestantisme Français, 1974) 451-487.

${ }^{39}$ Jean Bodin, De republica libri sex (Paris, 1586) 485. Machiavelli had reached the same conclusion in his analysis of Roman religion in Discorsi I, 11: "dove manca il timore di Dio, conviene o che quel regno rovini, o che sia sostenuto dal timore d'uno principe. . .E perché li príncipi sono di corta vita, conviene che quel regno manchi presto" (81).

${ }^{40}$ Bodin, De republica 485: "Et quemadmodum ex omni civitatum genere nullum deterius est anarchia, in qua nemo paret, nemo imperat, sed in summa scelerum omnium impunitate ac licentia vivitur: sic etiam nulla pestis civitatibus gravior acci-





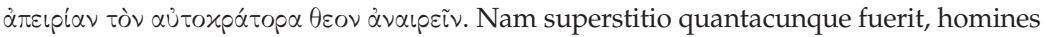
tamen in legum ac magistratuum metu et in mutuis vitae officiis continet: impietas autem adversus numina omnem ex anima peccandi metum penitus evellit."
} 
of a defense of religious tolerance initiated by another speaker, the nonsectarian Senamus, toward the beginning of book four. Coronaeus prefers superstition to atheism, or false religion to no religion, on the basis of the analogy between atheism and anarchy. ${ }^{41}$ Superstition has a political value for Coronaeus as a deterrent to misconduct because it supplies the fear of punishment and hope of reward denied by atheism. ${ }^{42}$ Coronaeus returns to the same theme at the beginning of book five where he declares that superstition is easier to tolerate than atheism:

Superstitio, quantacumque sit, quovis atheismo tolerabilior est; nam qui superstitione aliqua obligatur hunc numinis metus in officio quodammodo ac naturae legibus continet, atheum vero, qui nihil nisi testem metuit aut judicem, ad omnia scelera proclivi lapsu ruere oportet. ${ }^{43}$

What I would like to highlight in this last quotation from the Colloquium is the idea that the atheist fears nothing but a witness or a judge: "atheum. . .nihil nisi testem metuit aut judicem." The venerable theme of unwitnessed crime recalls the myth of Gyges from Plato's Republic. Atheism is like the ring of Gyges: it allows you to hide from your own conscience. By contrast, the superstitious man is convinced that he is always under surveillance, and this conviction is an invaluable instrument of social control.

This may seem like a rather cynical and utilitarian view of religion and it may have contributed to Bodin's posthumous reputation for atheism, but it is by no means a secret or clandestine doctrine. Bodin had already tried out this line of reasoning in his Method of History or Methodus ad facilem historiarum cognitionem of 1566 at the end of chapter 6 , the chapter devoted to a comparative study of different forms of government or status rerumpublicarum, which makes this chapter the closest in theme to the later work, Les six livres de la République. At the end of chapter 6, Bodin broaches the subject of the education of the prince or institutio principis, which is itself an important genre of Renaissance political philosophy. For Bodin, those charged with the education of the prince should focus not on foreign languages and other "pernicious and inept" subjects, as he calls them,

${ }^{41}$ Jean Bodin, Colloquium Heptaplomeres, ed. Ludwig Noack (Schwerin, 1857; reprint Stuttgart, 1966) 124: "Illud omnibus persuasum esse opinor, multo praestabilius esse falsam, quam nullam habere religionem, ut in omnibus rerum publicarum gentibus nullum perniciosius est $\alpha \nu \alpha p x i \alpha$, in qua nemo imperat, nemo paret, nulla praemia bonis, nulla supplicia peccatis irrogantur."

${ }^{42}$ Bodin, Colloquium 124: "Sic nulla est tanta superstitio, quae metu divini numinis improbos in officio continere et naturae lege quodammodo tueri non possit, cum praemia bonis, supplicia peccatis irrogari divino judicio persuasum habeant."

${ }^{43}$ Bodin, Colloquium 182-183. 
but rather they should concentrate on religion. ${ }^{44}$ As long as the prince is so indoctrinated or informatus as to think that god is the judge and spectator of all his actions, he will do nothing criminal, nor will he even think anything shameful. ${ }^{45}$ Such a prince will be an inspiration to his subjects and a model for them to follow. The situation of the prince is unique since, unlike his subjects, he cannot be deterred from crime by the fear of laws and magistrates. As Bodin asks, what magistrate, what laws, what powers will coerce the prince, unless he is held in check by fear of religion: "Principem vero quis magistratus, quae leges, quae imperia coercebunt, nisi religionis metu contineatur?" Here the prince plays the role assigned to the superstitious man in the passages we have already examined from the Republic and the Colloquium. He is contained or held in check by his religious belief that he is constantly under surveillance while the atheist enjoys impunity as long as none of his fellow citizens is looking. While Coronaeus in the Colloquium says of the superstitious man, "hunc numinis metus in officio continet," the Methodus says, "princeps religionis metu contineatur." Bodin rounds off his argument here in chapter 6 of the Method by appealing as usual to Polybius and other atheists, who recognize that religion is the surest foundation of political power. ${ }^{46}$ Given his enthusiasm for the same argument, it is no wonder that Bodin's name was soon added to the list of "numinis divini contemptores."

A century ago René Chauviré was struck by the frequency of Bodin's appeals to Polybius, which derive from book six of the Histories, devoted to the Roman constitution. ${ }^{47}$ At the end of book six, which was quite popular in the sixteenth century for its theory of the mixed constitution and its discussion of Roman military organization, Polybius addresses the role of religion in Roman statecraft. He declares that in his view what really unified Rome was something that

\footnotetext{
${ }^{44}$ Jean Bodin, Methodus ad facilem historiarum cognitionem, ed. Sara Miglietti (Pisa: Scuola Normale Superiore, 2013) 604: "consequens est ad unius Principis institutionem optimi sapientiae magistri ac moderatores, maximis propositis praemiis conquirantur: non qui peregrina lingua, id quod inepte ac perniciose antea factum vidimus, sed qui religione vera molles Principis animos leniter imbuant."

${ }^{45}$ Bodin, Methodus 604: "qui enim Princeps a disciplina sic erit informatus, ut suarum omnium actionum judicem ac spectatorem Deum esse cogitet, nihil impie, nihil scelerate faciet, nihil turpe cogitabit."

${ }^{46}$ Bodin, Methodus 604-606: "at etiam religionis tanta vis est ac maiestas, ut per sese. . .Principi adeo necessaria, ut nulla re magis imperium retineatur; quod etiamnum Aristoteles primum, deinde Polybius et Epicurus numinis divini contemptores fatentur."

${ }^{47}$ Chauviré, Colloque de Jean Bodin des secrets cachez des choses sublimes entre sept sçavans qui sont de differens sentimens (Paris: Champion, 1914) 51: "Ce passage [Polybe 6.56] avait vivement frappé Bodin."
} 
his Hellenistic audience regarded as shameful, namely superstition, $\tau \grave{\eta} \nu \delta \varepsilon \sigma \iota \delta \alpha \mu o v i \alpha \nu$ (6.56). If you could form a polity uniquely of wise men, you could do without superstition, but the only way to restrain


similar drama or $\operatorname{tp} \alpha \gamma \omega \delta i \alpha$. In other words, religion is a hoax and the Romans knew how to use it better than anyone else. It is the Greeks, he insists, who are wrong to disdain superstition and to value rationality more highly than social order. In this way, Polybius challenges his audience's values and praises what others blame. Bodin's own reflections on superstition belong to the same tradition as Polybius' Histories and Machiavelli's Discorsi, which is a tradition not only of political thought but also of epideictic rhetoric. ${ }^{48}$

In conclusion to this article, I would like to consider the implications of Bodin's treatment of superstition for the vexed question of his relationship to the Protestant Reformation and for the light it might shed on his personal dialogue with Michel de Montaigne, which is more often studied in relation to witchcraft trials and to the Démonomanie des sorciers than in relation to Bodin's political thought. ${ }^{49}$ For this purpose, we can consult Montaigne's "Apologie de Raymond Sebond," which was first published in 1580, in between the vernacular and the Latin version of the Republic. Alain Legros has drawn our attention to Montaigne's use of the word "superstition" as a synonym for Protestantism in his skeptical defense of religious orthodoxy in the "Apologie." ${ }^{150}$ In the long and sinuous course of his essay, Montaigne pauses in order to endorse the Christian condemnation of curiosity and pride:

Les Chrestiens ont une particuliere cognoissance combien la curiosité est un mal naturel et originel en l'homme. . . .L'orgueil est sa perte et sa corruption: c'est l'orgueil qui jette l'homme à quartier des voyes communes, qui luy fait embrasser les nouvelletez, et aimer mieux estre

\footnotetext{
${ }^{48}$ For the convergence of politics and rhetoric in the neo-Latin tradition, see the bibliography compiled by Marc Laureys in Discourses of Power: Ideology and Politics in Neo-Latin Literature, ed. Enenkel, Laureys, and Pieper (Hildesheim: Olms, 2012) xxix-xxxv.

${ }^{49}$ For Montaigne's reaction to Bodin's Démonomanie, expressed in the essay “Des boyteux" (III, 11), see Terence Cave, Pré-histoires. Textes troublés au seuil de la modernité (Geneva: Droz, 1999) 80-84; Rebecca Wilkin, Women, Imagination and the Search for Truth in Early Modern France (Ashgate, 2008) 169-177; and most recently Jean Bodin, De la démonomanie des sorciers, ed. Krause, Martin, MacPhail (Geneva: Droz, 2016) 48-49. For an excellent comparison of the two authors, see Raymond Esclapez, "Deux magistrats humanistes du XVIe siècle face à l'irrationnel: Montaigne et Bodin," Bulletin de la Société des Amis de Montaigne 7 (1987) 47-74.

${ }^{50}$ Alain Legros, Essais sur poutres (Paris: Klincksieck, 2000) 330-331.
} 
regent et precepteur d'erreur et de mensonge, que d'estre disciple en l'eschole de verité. ${ }^{51}$ II, 12,498

Pride draws us out of the beaten path and toward novelty, a term associated earlier in the essay with Martin Luther. The Christian attitude to pride reminds Montaigne of an ancient Greek saying: "C'est à l'avanture, ce que dict ce mot Grec ancien que la superstition suit l'orgueil et lui obeit comme à son pere: $\dot{\eta} \delta \varepsilon เ \sigma \iota \delta \alpha \mu o v i \alpha ~ \varkappa \alpha \tau \alpha \dot{\pi} \pi \varepsilon \rho \pi \alpha \tau \rho i$


Socratic apophthegm retrieved from Stobaeus' anthology, transcribed correctly on the beams of his library at the château de Montaigne as fol-

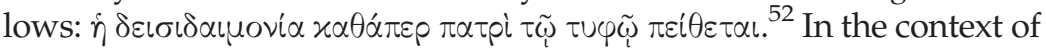
the French Wars of Religion, the superstition that follows pride and leads to novelty is the Protestant Reformation. Bodin may well have had in mind this passage from his illustrious contemporary when he rewrote his Republic in 1586.

It is even more likely that he was drawn to an earlier passage from the "Apologie" where Montaigne explains why he undertook to translate Sebond's Natural Theology from Latin into French at the request of his father, Pierre Eyquem, who received the book as a gift from the humanist pedagogue Pierrre Bunel, who intended it, rightly in Montaigne's estimation, as an antidote to the contagion of Lutheranism:

Entre autres, Pierre Bunel, homme de grande reputation de sçavoir en son temps, ayant arresté quelques jours à Montaigne en la compaignie de mon pere avec d'autres hommes de sa sorte, luy fit present, au desloger, d'un livre qui s'intitule Theologia naturalis. . .et le luy recommanda comme livre tresutile et propre à la saison en laquelle il le luy donna; ce fut lors que les nouvelletez de Luther commençoient d'entrer en credit et esbranler en beaucoup de lieux nostre ancienne creance. En quoy il avoit un tresbon advis, prevoyant bien, par discours de raison, que ce commencement de maladie declineroit aysément en un execrable atheisme. II,12,439

Bunel's "discours de raison," reported approvingly by Montaigne, is strangely at odds with Bodin's reason of state. Whereas for the humanist tourists gathered at the family estate, Lutheranism was a malady that could easily degenerate into atheism, from Bodin's vantage point, Protestantism, like any superstition, leads to atheism only when persecuted. Otherwise, when tolerated, it forms a bulwark against

\footnotetext{
${ }^{51}$ Michel de Montaigne, Les Essais de Montaigne, ed. Pierre Villey and V.L. Saulnier (Paris: PUF, 1978). The essays are cited according to book, chapter, and page.

${ }^{52}$ Legros 330 and Stobaeus, Anthologium, ed. Wachsmuth and Hense, vol. 3 (Berlin, 1894) 593.
} 
impunity and disorder and conduces to the health of the state. In this respect, if not in any other, Bodin may have gotten the better of Montaigne.

Thus Bodin's treatment of superstition, when juxtaposed with Montaigne's use of the term, can be taken as an admittedly invidious defense of Protestantism. He conducts this defense not in theological terms but in terms of reason of state, appealing to a utilitarian scale of values decried by Catholic and Protestant apologists alike. By the time Ben Jonson wrote his comedy Volpone in 1606, Bodin was already ensconced in the popular imagination, on an international scale, as a colleague of Machiavelli and a professor of atheism, which was the only thing, in fact, that he was not prepared to tolerate. 